\title{
A Student-Centred Experience at a Brazilian Summer Course for Student Teachers
}

\author{
Juliana Crespo Lopes ${ }^{1}$, Anne Nevgi ${ }^{2}$, Lucia Helena Cavasin Zabotto Pulino ${ }^{3}$ \\ ${ }^{1} \mathrm{FUP} / \mathrm{UnB}$, Universidade de Brasília, Brasília, Brazil \\ ${ }^{2}$ Faculty of Education, University of Helsinki, Helsinki, Finland \\ ${ }^{3}$ Psychology Institute, Universidade de Brasília, Brasília, Brazil \\ Email: juliana.jcl@gmail.com
}

How to cite this paper: Lopes, J. C., Nevgi, A., \& Pulino, L. H. C. Z. (2019). A StudentCentred Experience at a Brazilian Summer Course for Student Teachers. Creative Education, 10, 2028-2044. https://doi.org/10.4236/ce.2019.109148

Received: August 28, 2019

Accepted: September 24, 2019

Published: September 27, 2019

Copyright () 2019 by author(s) and Scientific Research Publishing Inc. This work is licensed under the Creative Commons Attribution-NonCommercial International License (CC BY-NC 4.0). http://creativecommons.org/licenses/by-nc/4.0/

\begin{abstract}
Background: This paper refers to an empirical study held at an undergraduate summer course for student teachers at a public Brazilian University, aiming to promote teaching and learning processes based on a student-centred approach. Methods: The study was set up as a Pedagogical Action Research. The classes were initially planned based on interviews with teachers and students from the regular previous term and on open-answers questionnaires filled in by students enrolled at the summer course. At the end of the summer course, a new open-answer questionnaire was filled in by the students. Results: It was possible to perceive a positive change on students' postures, engagement and learning, and will become teachers. Conclusions: The findings indicate that student-centred practices are an interesting pedagogical approach for Teacher Education. Besides going further with the Pedagogical Action Research it is perceived the need to make similar studies at different Brazilian Higher Education settings.
\end{abstract}

\section{Keywords}

Student-Centred, Teaching, Learning, Teacher Education

\section{Introduction}

This paper refers to an empirical study held at an undergraduate summer course for student teachers at a public Brazilian University, aiming to promote teaching and learning processes based on a student-centred approach. Brazilian Universities are expected to report annually their activities and outcomes to the government. In the Annual Report are presented results of a survey in which students and teachers give their feedback of the teaching and learning at the university. 
An analysis of four Universities Annual Reports (UFAM, 2015; UFRJ, 2016; UnB, 2016; UTFPR, 2015), has shown that students scored lowest on the teachers' pedagogical skills. In Brasilia University Annual Reports (UnB, 2012, 2013, $2014,2015,2016)$ the items about teachers' “Ability to promote students' interest about subjects of study" and "use of a teaching strategy that facilitates learning" received the lowest scores from students in the past five years. When the students are asked about their self-evaluation, most of them consider themselves surface learners. Regarding this last data, the University Report (UnB, 2014) states that students are aware of the necessity of being more proactive about their learning. Rio de Janeiro Federal University (UFRJ, 2016) highlights that students persistently complain about outdated and low flexibility curricula, old-fashioned pedagogical approaches and a poor connection between theory and practice, relating these issues to students drop outs. According to the last Brazilian Higher Education Census (INEP, 2016) 127,209 student teachers started their studies at Public Universities in 2010 but only 71,957 of them graduated in 2014 . This means that $44 \%$ of student teachers did not finish studies on time or dropped out University.

Many Universities from different countries are concerned about university teachers thinking and pedagogical skills, and, therefore, are researching and offering training in order to improve them (Gibbs \& Coffey, 2000; Gibbs \& Coffey, 2004; Postareff, Lindblom-Ylanne, \& Nevgi, 2007; Stes, Gijbels, \& van Petegem, 2008; Prosser \& Trigwell, 1997). For the past decades, some innovative teaching approaches are being held in Brazil, mostly related to technology use (Caliari, Zilver, \& Perez, 2017), Problem-Based Learning in Business (Escrivão Filho \& Ribeiro, 2008; Borochovicius \& Tortella, 2014) Med (Coelho Filho, Soares, \& Sa, 1998; Galvão, Azevedo-Vaz, \& Oliveira, 2016) and Technology Schools (Ribeiro, 2008; Garcia, 2014) or Gamifying Education (Fragelli \& Fragelli, 2017; Silva Junior, 2017).

Regarding Teacher Education, the only innovative approach that was found is related to the use of technology, mainly at Distance Learning, very common in Brazil due to the National Education Plan (Ministério da Educação, 2014) that states at its 15th Aim that all school teachers should have Higher Education degree. In order to achieve that, considering the fact that some areas of Brazil are scarce in Higher Education Institutions, Distance Learning has been seen as a good solution. Nevertheless, it was/still is an emergencial policy often more concerned with quantity than quality (Arruda \& Arruda, 2015) and that does not meet student teachers educational needs (Nunes \& Sales, 2013). David (2017) advocates for implementing a student-centred course of parasitology based on the fact that there are many medical and veterinary challenges that could benefit from actively engaged students and higher level thinking. From the same perspective, it is possible to think about Brazilian educational challenges, that go from low achievement, lack of interest for learning, school drop outs (Martins, 2012) to the need of enhancing teachers quality and reduce teachers drop outs 
(Bauer, Cassettari \& Oliveira, 2017), that could benefit from Teacher Education courses with student-centred approaches.

In the research focusing on university teachers' concepts of teaching and approaches to teaching, the two diverse approaches to teaching have been identified: content-centred and teacher-focused versus learning-centred and student-focused (Kember \& Kwan, 2000; Trigwell \& Prosser, 1996; Prosser, Trigwell, \& Taylor, 1994; Postareff, Lindblom-Ylanne, \& Nevgi, 2007; Postareff \& Lindblom-Ylänne, 2008). In the content-centred and teacher-focused approach to teaching, university teachers perceive teaching as more traditional lecturing, and the main focus is on the teacher and his/her role transmitting knowledge. In the latter, learning-centred and student-centred approach to teaching, university teachers focus on students' learning and seek for active and deep learning, and, therefore, student's responsibility, accountability and autonomy. In the student-centred approaches, the relationship between students and teachers is grounded in mutual respect and reflexion about teaching and learning process (Lea, Stephenson, \& Troy, 2003).

The use of teaching methods based on student-centred approaches at Higher Education has been broadly discussed and practiced in institutions all over the world. There are several pedagogical practices that can be called student-centred, at this article the focus is on pursuing students' interest, motivation, deep learning and autonomy. The idea that a student will learn better when interested in the topic of study is a widespread idea (Renninger \& Hidi, 2016), if a teacher seeks for students' interest, instead of having a strictly disciplinary structure of contents, s/he should plan the classes based on the student interests (Ferreira, Carpim, \& Behrens, 2013). In that case, it is not the student who should get interested in the topic, the topic needs to be dealt in an interesting way for the student. It is important to note that teachers' student-centred approach won't necessarily promote deep approaches in learning (Postareff, Lindblom-Ylanne, \& Nevgi, 2007).

Entwistle, Hughes \& Mighty (2010) define deep approaches in learning as processes that "can lead to tight, integrated forms of understanding and to an awareness of their understanding as a knowledge object" (p. 30). The authors continue stating that courses can encourage deep approaches in learning by making clear, since the beginning, what is expected from them both in thinking and practice. The teacher must use lively and clear explanations and adequate language. Moreover, it is important to exemplify ways of thinking and practising, to give the possibility of choosing assignments, work with real problems and to be alert to notice and deal with possible difficulties that may appear. McDonald, Reynolds, Bixley, \& Spronken-Smith (2017) suggest 6 principles to encourage deep approaches in learning: 1) Alignment of course outcomes with taught material and with assessment model; 2) transformative learning experiences such as the opportunity to develop practical skills; 3) Discussion of lecture and laboratory material with peers and lecturers; 4) assessment that encou- 
rages a deeper approach in learning; 5) Considering the student workload and 6) regular teaching workshops.

A common critique made about the university is that many graduates find difficulties in solving complex real-life problems by using their academical knowledge (Stes, Gijbels, \& Van Petegem, 2008). That situation is difficult to solve with traditional teaching approaches, according to Sun, Liu, Wu, \& Li (2014). The authors advocate that student-centred approaches stimulate study, thinking and practice abilities because instead of being passive in the classroom, imitating teachers' explanations and demonstrations, they are active in the learning process, developing independent thinking and self-regulated study.

Self- and co-regulation skills are really important for students to be able to manage their time and effort focused on studies, thus increasing involvement and decreasing drop-outs (Hailikari \& Parpala, 2014). Actions that can help the development of self- and co-regulation skills include collaborative learning and self- and peer-assessment (Räisänen, Postareff, \& Lindblom-Ylänne (2016). Regarding assessments, David (2017) cites a pedagogical student-centred experience where open-ended group activities promoted more students participation on discussion about real-life situations. Due to the fact that grades were given upon participation, students felt stimulated to share their thoughts, not worrying about being right or wrong. This posture made possible for students to practice hypothesizing and also that misconceptions and inaccuracies were known and better understood.

Universities should promote learning environments where students are active in their learning processes, producing their own knowledge instead of just repeating what teachers say (Stes, Gijbels, \& Van Petegem, 2008). According to the authors, in order to achieve this goal, the teachers' actions and postures are fundamental. McDonald, Reynolds, Bixley \& Spronken-Smith (2017) present the results of a study showing strategic and deep student approaches increasing with changes in the learning environment, teaching, activities and assessments. It is also taken into consideration the development of students abilities during the three years that the study was carried on.

\section{Methods}

This study aimed to answer the following questions:

1) How students and teachers perceive the importance of teacher training?

2) What kind of experiences student teachers have at a course based on traditional teaching methods?

3) What kind of experiences student teachers have at a course based on student-centred approaches?

\subsection{Research Approach: A Case Study of Action Research}

The study is a case study and applies Action Research approach, more specifically a Pedagogical Action Research approach, which is defined by Norton 
(2008) as a procedure for teachers to investigate and reflect about her/his own teaching/learning facilitation practice and improve it. The first author designed the case study to follow the five steps of an action research:

Step 1: Identifying a problem/paradox/issue/difficulty;

Step 2: Thinking of ways to tackle the problem;

Step 3: Doing it;

Step 4: Evaluating it (actual research findings);

Step 5: Modifying future practice (Norton, 2008: p. 70).

For the purpose of this study, the first two steps were conducted in two phases, labeled Study A and Study B. Study A was exploratory study and Study B, after a previous exploratory part, was put into practice.

\section{Ethics}

All the participants have signed an Informed Consent Form. Because it was a research part of University Notice calling from practices that would improve undergraduate education, there was no need to pass through the Ethics Committee.

\subsection{Context of the Study}

The study was conducted at Brasilia University, a public federal institution, regarding the undergraduate course "Psychological Development and Teaching" from the Teacher Education curriculum. All the students were from careers that lead to school or language teaching, such as Art, Japanese and Maths. The teachers were doctoral students or professors from the Psychology Institute.

Study A consisted on interviews with four teachers who taught "Psychological Development and Teaching" course with traditional teacher-centred approaches ( 2 professors and, 2 doctoral students) and 12 students who were taking the course with these teachers. Study B was held on a "Psychological Development and Teaching" course, but that was offered as a summer course, with the same amount of credits and was developed based on a student-centred approach. The classes happened every morning, from Monday to Friday, for three hours, during 15 days. After that period, the students had 10 days to elaborate the assessments, with e-mail feedbacks whenever it was requested.

At the first class of Study B, students talked about what they would like to learn at the course and answered open-ended questionnaires about themselves as students and opinions and suggestions to make classes better. Students were told that the course would be part of an Action Research and that their suggestions would help planning the classes. At the second day, the teacher presented the teaching plan, designed from the students interests and suggestions and also based on the items of the Trigwell \& Posser's Approaches to Teaching InventoryConceptual Change/Student Focused part, summarized by Postareff (2007) and McDonald, Reynolds, Bixley, \& Spronken-Smith (2017) principles to encourage deep approaches in learning. The assessment plan was decided collectively and comprised creating a teaching plan regarding their fields of study and self-evalua- 
tion with daily reflections. The classes were divided into four sessions (Table 1).

\subsection{Participants}

At Study A, the interviewed teachers were from the Psychology Institute of Brasilia University and the students were from different careers focused on teaching who were enrolled at Psychological Development and Teaching courses given by those teachers. Research assistants contacted all the 6 teachers responsible for the discipline and four of them were willing to participate. After that, research assistants present themselves at classes from these teachers looking for volunteered students. Twelve students manifest interest in participating in the research and gave their telephone numbers to be contacted later.

At Study B, the teacher was the first author of this paper, a doctoral student from the Psychology Institute. The students were from different careers focused on teaching who were enrolled at Psychological Development and Teaching course offered at summer, with the same credits as the regular course. At the first class it was explained the purpose of the class and research and all the students agreed on participating. At the beginning of the course, 34 students answered the questionnaires. At the end of the course, this number dropped down to 27 students.

\subsection{Instruments}

Study A consisted on semi-structured interviews, because it was a small-scale research where the main focus was on the quality of information that could be

Table 1. Design of classes at the student-centred course.

\begin{tabular}{|c|c|c|c|}
\hline Session & Quantity & Topics & Practices \\
\hline 1 & Six classes & 5 main authors and review & $\begin{array}{l}\text { Theoretical explanations and } \\
\text { small/big group discussions }\end{array}$ \\
\hline 2 & Four classes & $\begin{array}{l}\text { Theory applied to students' } \\
\text { field of study (Maths, } \\
\text { Physics, Languages, } \\
\text { Humanities and Arts) }\end{array}$ & $\begin{array}{l}\text { Two classes with theoretical } \\
\text { discussions and group work } \\
\text { planning practical class activities } \\
\text { Two classes with class activities } \\
\text { practical experiences }\end{array}$ \\
\hline 3 & Three classes & $\begin{array}{l}\text { Psychological topics } \\
\text { (Attention Disorder, } \\
\text { Autism, Atypical } \\
\text { development and inclusion) }\end{array}$ & $\begin{array}{l}\text { Small and big group discussion, } \\
\text { Questions \& Answers session, } \\
\text { group work planning practical } \\
\text { class activities. } \\
\text { One class with class activities } \\
\text { practical experiences. }\end{array}$ \\
\hline 4 & Two classes & $\begin{array}{l}\text { Teacher-student } \\
\text { relationship } \\
\text { Review and closure }\end{array}$ & $\begin{array}{l}\text { A talk with a teacher from the } \\
\text { University, responsible for } \\
\text { engineering courses with } \\
\text { small failure rate } \\
\text { Review of course contents with a } \\
\text { small groups game and reflection } \\
\text { about the summer course classes }\end{array}$ \\
\hline
\end{tabular}


obtained by a focused conversational two-way communication, which is supported by Drever (1995) and Pathal \& Intratat (2012). The topics covered on the interviews were related to opinions about the discipline, teachers and students postures, and suggestions to make the course "Psychological Development and Teaching" better.

At Study B, the number of participants was higher and, specially, there was not much time available since the main purpose was to put into practice the suggestions made in both studies. Another important aspect was to assure the students full anonymity to express their opinions, to pursue a not biased data: neither too positive looking for good grades, nor silencing possible criticisms. The chosen instruments were open-end questionnaires, answered twice, at the beginning and at the end of the course, with the following questions:

The first-day questionnaire was exploratory and comprised the following questions:

- What were the reasons for your career choice?

- Is this your first undergraduation course? If not, what was the career?

- Would you like to change your career? If so, why?

- What is your opinion about becoming a teacher?

- What is your opinion about the Teacher Education courses?

- What are your expectations (including the negatives) about this course?

- How do you see yourself as a student?

- How do you learn?

- What teachers could do to make classes better?

The last questionnaire had the following questions:

- How did you see yourself as a student in this course?

- How did you learn in this course?

- What were the positive and negative highlights of the pedagogical practices of the course?

- What is your opinion about the course?

- Were your expectations met? Which ones?

- Do you want to become a teacher?

- If you were the teacher of this course, what would you do differently?

Singer and Couper (2017) claim that open-ended questions are important because they increase participants' sense of engagement and also provide more detailed data. In the particular case of the study, we aimed to provide not only sense, but real students' engagement and participation at the course, since its elaboration and execution. It is important to note that some numbers will extrapolate the number of participants, this happened because students from Study B often gave complete answers, providing plenty information.

\subsection{Analyses}

The research had a qualitative approach and used thematic analysis for the final questionnaires analysis. Thematic Analysis is seen as a good option when work- 
ing with learning and teaching processes because the diversity education has in it benefits from a more flexible method, not tied to a particular perspective (Maguire \& Delahunt, 2017). At the exploratory study, made with the interviews and a questionnaire at the beginning of Study B, the suggestions, critiques, interests and approaches to study were categorized to identify issues and to plan an approach to deal with them at Study B classes.

\section{Results}

All teachers perceive that undergraduate student teachers do not understand the importance of the Psychology Development and Teaching course and are enrolled at the course just because it is mandatory. Study A students' opinions about their own posture at the course are shown in Table 2 and about what could be improved in classes in Table 3:

Students from Study B prior to classes saw themselves mostly as interested and dedicated students (nineteen); five acknowledged that they could be more dedicated students; three described themselves as lazy and relapsed students and added that wanted to change this situation. One student qualified herself as a terrible student, another one as a regular and the last one as a frustrated student. Four did not answer.

When asked about the reasons for choosing a teaching career, Study A answers were more related to employment (7 of 12 students). All students gave also other explanations, each one with four mentions: had inspiring school teachers, willing to "make the difference" and relating the choice as an innate condition. At Study B, most parts of the students (29 of 34) explained to have chosen their career because are interested about the subject (physics, mathematics, languages). The expressions "love" and "passion" were used 6 times to express this interest. Only two related the choice to employment, one wanted to "make a difference", one did not answer and one said that it was because of lack of options.

Table 4 shows how students from Study B perceive their future as teachers, both prior summer course classes and afterwards. Although seven students did not reply to the second questionnaire, it was possible to find at the written answers a positive change.

Table 2. Students' postures at teacher training courses.

\begin{tabular}{cc}
\hline Not participant/not aware & 9 \\
Interested in classes & 3 \\
\hline
\end{tabular}

Table 3. Possible improvements in classes.

\begin{tabular}{cl}
\hline Students being more participative & 9 \\
Better teacher's didactics & 6 \\
Did not know how to answer & 4 \\
\hline
\end{tabular}


Table 4. Students' willingness to become teachers.

\begin{tabular}{cc}
\hline & Before classes \\
\hline Yes & 28 \\
Not decided & 2 \\
Probably not & 2 \\
No & 1 \\
Did not answer & 1 \\
\hline Yes & \\
\hline Possibly & \\
No & 20 \\
\hline & \\
\hline
\end{tabular}

1) Students' experiences of learning in student-centred course-Study B

When students were asked about how they learn, 24 of the 34 students listed individual methods such as reading and watching videos. More than one manner was appointed by most part of students; the other methods were (Table 5):

Regarding their expectations at the beginning of the course, 24 students wished it helped them being good teachers. 2 students missed the first class, answered the questionnaire on arrival and reported that after attending the first class, have come to have good expectations. The other topics are presented in Table 6 and Table 7.

2) Students' experiences of learning in Course $B$

The content analysis of the open-end answers yielded in five categories shown at Table A1 (see Appendix): 1) Students stating that prior to the course they did not want or did not consider becoming school teachers and, after classes, are willing/thinking more often about to pursue this professional path; 2) Students reporting a growth at their dedication and effort to study; 3) Significant learning to become a good teacher and proper learning; 4) Opinions about classes being good and motivational; 5) Surprised with teaching practices and their own postures as students.

There was a student whose questionnaire did not contain any of the themes listed and neither brought other shared topics. It showed insatisfaction with the pedagogical approaches, pointing out that she learned only by her reading at home and did not feel interested in classes.

Students of the both courses (traditional and student-centred) emphasised in their answers the importance of active learning to improve their engagement and learning in teacher education. In Table 8, students' suggestions to improve the classes are presented.

The latter two suggestions were made only by students from Study A, based on the experience they were having at the course at the time of the interview. 
Table 5. Students' learning activities in the student-centred course.

\begin{tabular}{cc}
\hline Practical activities and dynamic classes & 11 \\
Classes explanations & 9 \\
Debates & 3 \\
Examples & 3 \\
Teaching & 1 \\
\hline
\end{tabular}

Table 6. Students' expectations for learning in the student-centred course.

\begin{tabular}{cc}
\hline To experience a good course & 6 \\
Worried about the reading load & 4 \\
To become better students & 2 \\
No expectations & 2 \\
To be approved & 2 \\
\hline
\end{tabular}

Table 7. Students opinions about teacher education courses were mainly positive, but with some diversions.

\begin{tabular}{cc}
\hline Important and necessary & 13 \\
Interesting & 13 \\
Did not like humanities courses & 5 \\
Previous bad experiences & 3 \\
First experience, no opinion formed & 3 \\
\hline
\end{tabular}

Table 8. Students' suggestions to improve the classes in both exploratory studies.

\begin{tabular}{cc}
\hline Suggestions & N. of students \\
\hline More interaction, participation, practical and contextualized activities & 29 \\
Dialog and respect between teachers and students & 7 \\
Deepening at theory & 5 \\
More objectivity & 3 \\
\hline
\end{tabular}

\section{Discussion}

Students from Study A seemed to be less motivated, had fewer opinions (the answer "I don't know" was said repeatedly). Moreover, their self-perception as students wasn't good and they were mainly not interested in the Psychological Development and Learning course. Students from Study B seemed to be more motivated, with a better self-perception as students and affirming to be more interested in the course.

One possibility for this to happen is because students start a course interested in it, but as the classes go by, they lose their interest. At the same time, there is an expectation that courses (in general or from the Teacher Education curriculum specifically) will be unpleasant, even if it is not verbalized. Most parts of students from Study B expressed an expectation for the course to be useful and, at the end of it, some admitted that the first expectation, before classes started, 
was negative. Maybe, because they perceived themselves as being part of the course construction, with a teacher being interested at their opinions and suggestions, they felt more motivated to contribute and experience the classes (Singer \& Couper, 2017).

When explaining the reasons for the chosen career, the high possibility of employment was often stated in Study A, while at Study B the reasons for the chosen career were related to intrinsic motives. The need for an employment assurance is a good reason to not quit studies. Considering the big rates of drop outs among student teachers in Brazil (INEP, 2016) and that a Federal University related it to outdated and low flexibility curricula, old-fashioned pedagogical approaches and a poor connection between theory and practice (UFRJ, 2016), if a student is not satisfied with pedagogical approaches at University, the need of a diploma to pursue employment is what keeps the student somehow motivated, rather than personal reasons. Because students from Study B were feeling more engaged in the course construction, there was no need for an external reason to believe in the importance of the chosen career for their future.

For the specific course of Study B Action Research, all the suggestions were put into practice, as well as students' difficulties, criticisms and obstacles were taken into consideration. That is the initial understanding of student-centred this study has: students are the center of the learning processes and classes have to be a collective construction. At Study B all students suggestions were pedagogical practices understood as student-centred or deep learning encouragement: Active students (Stes, Gijbels, \& Van Petegem, 2008); relationship respect between teacher and students (Lea, Stephenson, \& Troy, 2003) and work with real problems (Entwistle, Hugues, \& Mighty, 2010).

One concern of this Pedagogical Action Research was to encourage deep approaches in learning, from the 6 principles suggested by McDonald, Reynolds, Bixley, \& Spronken-Smith (2017) only one item, regular teaching workshops, was not possible to fulfill. Also, Postareff's reflexions about student-focused approach were part of the everyday pedagogical planning and practices.

From the themes that emerged from the second questionnaire of Study B it was possible to see that student teachers not only had good experiences at a course based on student-centred approach but also that it was seen as useful for future professional practices, even helping supporting the career decision. The course also was seen as important for the development of studying practices.

About the will to become a teacher, at the first questionnaire 2 students had not decided; other 2 answered that it was unlikely; 1 replied negatively and 1 did not answer. At the last questionnaire, only 2 answered negatively and 4 affirmed to be considering it as a possibility. More specifically, at four questionnaires appeared the idea of changing opinion towards being a teacher because of good experiences at the course. Having a positive experience as a student can motivate the aspiration of being a good teacher, a fact that can help decreasing drop outs at Teacher Education careers. This added to the fact previously discussed about 
reasons for career choice indicates that feeling and being part of a course is important for student teachers' professional future.

Sixteen students reported a growth on dedication and effort on studies because of the pedagogical approach used at the course. It included a raise of awareness of the challenges they face as students and the need to find out ways to learn more and better. These are self-regulation skills, important to increase involvement and decrease drop-outs (Hailikari \& Parpala, 2014) and to stimulate study, thinking and practice abilities (Sun, Liu, Wu, \& Li, 2014). Thus, the practice reduced the lack of students' commitment with classes that appeared as teachers' complaints and students' self-criticism on Study A. Additionally, students learn how to study and learn in different ways than by individually, as it was reported at the first questionnaire.

The recurrent theme (mentioned by 21 students) good and motivational classes showed that student-centred pedagogical approaches promote students' interests about subjects of study and that the teaching strategies used facilitated learning, the items that had lowest scores at the last five Annual Reports of the University where this study happened ( $\mathrm{UnB}, 2012,2013,2014,2015,2016)$. It is interesting to note that more than half of students were surprised with the course teaching practices and their own involvement with it, showing that university students are not expecting classes to be good or that they will be interested and engaged at studies. University can be more than a path to a curriculum; it can be a place to learn, practice, reflect, being active at knowledge production and to develop as a whole human being. Significant learning was a theme expressed by 16 students, regarding two specific learnings: useful knowledge for professional life and proper learning of the course subjects. The student who was enrolled at the course for the third time said that could learn better at the course. Although most part of students can be at least average students, there are some who need a different approach to be able to get interested, motivated and learn. More than that, this knowledge has to be applied on their future occupation, which was one of the major expectations students expressed on the first questionnaire: 24 students hoped the course would help them being good teachers. Theory is often disconnected from practice (UFRJ, 2016), making more difficult for students to engage at deep learning approaches to study, leading to a possible professional with surface knowledge and practice.

\section{Conclusion}

Teaching methods based on student-centred approaches showed to be interesting practices to deal with the high rate of complaints about teaching methods at the Brazilian Universities Annual Reports, the urge to decrease student teachers drop outs and to increase the quality of the future school teachers.

We propose a teacher education that not only reproduces knowledge and pedagogical practices but also encourages student-teachers to produce knowledge and to think and propose strategies to reconfigure the format and dynamics of 
the classes, with greater student participation.

This type of educational practice makes teachers and students aware of their importance and responsibility in the teaching-learning process. Writing a learning journal, evaluating yourself and the teacher procedurally, and building the course plan collectively are all part of the awareness-raising process that enhances student-centred teaching.

The experiences reported by student teachers at the course were important to support the course's student-centred approach and also gave important feedbacks to go further with this Educational Action Research, next time at a regular course. It is suggested to carry out more studies with student-centred approaches at Brazilian Higher Education, beyond teacher education.

\section{Conflicts of Interest}

The authors declare no conflicts of interest regarding the publication of this paper.

\section{References}

Arruda, E., \& Arruda, D. (2015). Educação à distância no Brasil: Políticas Públicas e democratização do acesso ao Ensino Superior. Educação em Revista, 31, 321-338. https://dx.doi.org/10.1590/0102-4698117010

Bauer, A., Cassettari, N., \& Oliveira, R. (2017). Políticas docentes e qualidade da educação: Uma revisão da literatura e indicações de política. Ensaio: Avaliação e Políticas Públicas em Educação, 25, 943-970. https://doi.org/10.1590/s0104-40362017002501010

Borochovicius, E., \& Tortella, J. (2014). Aprendizagem Baseada em Problemas: Um método de ensino-aprendizagem e suas práticas educativas. Ensaio: Avaliação e Políticas Públicas em Educação, 22, 263-294. https://doi.org/10.1590/S0104-40362014000200002

Caliari, K., Zilber, M., \& Perez, G. (2017). Tecnologias da informação e comunicação como inovação no ensino superior presencial: Uma análise das variáveis que influenciam na sua adoção. Revista de Gestão, 24, 247-255. https://doi.org/10.1016/j.rege.2017.05.003

Coelho-Filho, J., Soares, S., \& Sá, H. (1998). Problem-Based Learning: Application and Possibilities in Brazil. Sao Paulo Medical Journal, 116, 1784-1785. https://doi.org/10.1590/S1516-31801998000400009

David, A. A. (2017). A Student Centered Framework for Teaching Undergraduate Parasitology. Trends in Parasitology, 33, 420-423. https://doi.org/10.1016/j.pt.2017.01.010

Drever, E. (1995) Using Semi-Structured Interviews in Small-Scale Research. A Teacher's Guide. Edinburgh: Scottish Council for Research in Education.

Entwistle, N., Hughes, J., \& Mighty, J. (2010). Taking Stock: An Overview of Research Findings (pp. 15-51). Research on Teaching and Learning in Higher Education. https://www.research.ed.ac.uk/portal/files/14426330/ENTWISTLE_Taking_Stock.pdf

Escrivão Filho, E., \& Ribeiro, L. (2008). Inovando no ensino de administração: Uma experiência com a aprendizagem baseada em problemas (PBL). Cadernos EBAPE.BR 6, 1-9. https://doi.org/10.1590/S1679-39512008000500004

Ferreira, J. L., Carpim, L., \& Behrens, M. A. (2013). The University Professor Who Builds 
up Innovative Knowledge for a Complex, Collaborative and Dialogical Practice. Revista Diálogo Educacional, 13, 69-84. https://doi.org/10.7213/dialogo.educ.7627

Fragelli, R., \& Fragelli, T. (2017). Summaê: Um espaço criativo para aprendizagem. Revista Diálogo Educacional, 17, 409-430. https://doi.org/10.7213/1981-416X.17.052.DS05

Galvão, N., de-Azevedo-Vaz, S., \& Oliveira, M. (2016). O método de aprendizagem baseada em problemas na disciplina de Radiologia Odontológica. Revista da ABENO, 16, 72-78. https://revabeno.emnuvens.com.br/revabeno/article/view/350 https://doi.org/10.30979/rev.abeno.v16i4.350

Garcia, G. P. (2014). O Ensino de Engenharia e o Método PBL. In Seminário Internacional de Educação Superior-Formação e Conhecimento (pp. 1-11). Sorocaba: Universidade de Sorocaba.

https://uniso.br/publicacoes/anais_eletronicos/2014/4_es_praticas_educacionais/07.pdf

Gibbs, G., \& Coffey, M. (2000). Training to Teach in Higher Education: A Research Agenda. Teaching in Higher Education, 4, 31-44.

https://doi.org/10.1080/13664530000200103

Gibbs, G., \& Coffey, M. (2004). The Impact of Training of University Teachers on Their Teaching Skills, Their Approach to Teaching and the Approach to Learning of Their Students. Active Learning in Higher Education, 5, 87-100.

https://doi.org/10.1177/1469787404040463

Hailikari, T., \& Parpala, A. (2014). What Impedes or Enhances My Studying? The Interrelation between Approaches to Learning, Factors Influencing Study Progress and Earned Credits. Teaching in Higher Education, 19, 812-824.

https://doi.org/10.1080/13562517.2014.934348

INEP (2016). Censo da Educação Superior. http://inepdata.inep.gov.br

Kember, D. and Kwan, K. (2000). Lecturers' Approaches to Teaching and Their Relationship to Conceptions of Good Teaching. Instructional Science, 28, 469-490. https://doi.org/10.1023/A:1026569608656

Lea, Stephenson, S., \& Troy, J. (2003). Higher Education Students' Attitudes to Student Centred Learning: Beyond "Educational Bulimia". Studies in Higher Education, 28, 321-334. https://doi.org/10.1080/03075070309293

Maguire, M., \& Delahunt, B. (2017). Doing a Thematic Analysis: A Practical, Step-by-Step Guide for Learning and Teaching Scholars. AISHE-J, 9, 3351. http://ojs.aishe.org/index.php/aishe-j/article/view/3354

Martins, E. (2012). Educação e serviço social: Elo para a construção da cidadania. São Paulo: Editora UNESP. https://doi.org/10.7476/9788539302437

McDonald, F., Reynolds, J., Bixley, A., \& Spronken-Smith, R. (2017). Changes in Approaches to Learning over Three Years of University Undergraduate Study. Teaching \& Learning Inquiry, 5, 65-79. https://doi.org/10.20343/teachlearninqu.5.2.6

Ministério da Educação (2014). Plano Nacional de Educação: Conhecendo as 20 metas. http://pne.mec.gov.br/images/pdf/pne_conhecendo_20_metas.pdf

Norton, L. A. (2008). Action Research in Teaching and Learning: A Practical Guide to Conducting Pedagogical Research in Universities. Routledge: New York.

Nunes, J., \& Sales, V. (2013). Formação de professores de licenciatura a distância: o caso do curso de pedagogia da UAB/UECE. Educação e Pesquisa, 39, 757-773. https://dx.doi.org/10.1590/S1517-97022013000300013

Pathal, A., \& Intratat, C. (2012) Use of semi-structured interviews to investigate teacher perceptions of student collaboration. Malaysian Journal of ELT Research, 8, 1-10. 
https://journals.melta.org.my/index.php/majer/article/view/149

Postareff, L. (2007). Teaching in Higher Education: From Content-Focused to Learning-Focused Approaches to Teaching. Academic Dissertation. University of Helsinki, Helsinki, Finland. https://helda.helsinki.fi/handle/10138/19882

Postareff, L., \& Lindblom-Ylänne, S. (2008). Variation in Teachers' Descriptions of Teaching: Broadening the Understanding of Teaching in Higher Education. Learning and Instruction, 18, 109-120. https://doi.org/10.1016/j.learninstruc.2007.01.008

Postareff, L., Lindblom-Ylanne, S., \& Nevgi, A. (2007). The Effect of Pedagogical Training on Teaching in Higher Education. Teaching and Teacher Education, 23, 557-571. https://doi.org/10.1016/j.tate.2006.11.013

Prosser, M., \& Trigwell, K. (1997). Relations between perceptions of the teaching environment and approaches to teaching. British Journal of Educational Psychology, 67, 25-35. https://doi.org/10.1111/j.2044-8279.1997.tb01224.x

Prosser, M., Trigwell, K. \& Taylor, P. (1994). A Phenomenographic Study of Academics' Conceptions of Science Learning and Teaching. Learning and Instruction, 4, 217-223. https://doi.org/10.1016/0959-4752(94)90024-8

Räisänen, M., Postareff, L., \& Lindblom-Ylänne, S. (2016). University Students' Self- and Co-Regulation of Learning and Processes of Understanding: A Person-Oriented Approach. Learning and Individual Differences, 47, 281-288.

https://doi.org/10.1016/j.lindif.2016.01.006

Renninger, K. A., \& Hidi, S. (2016). The Power of Interest for Motivation and Learning. New York: Routledge. https://doi.org/10.4324/9781315771045

Ribeiro, L. (2008). Aprendizagem baseada em problemas (PBL): Uma experiência no ensino superior. São Carlos (SP): EdUFSCar. https://doi.org/10.7476/9788576002970

Silva Júnior, S. (2017). Gamificação em ambientes educacionais ubíquos. Master’s Thesis, Uberlândia: Universidade Federal de Uberlândia.

https://repositorio.ufu.br/handle/123456789/18330

Singer, E., \& Couper, M. (2017). Some Methodological Uses of Responses to Open Questions and Other Verbatim Comments in Quantitative Surveys. Methods, Data, Analyses, 11, 20. https://doi.org/10.12758/mda.2017.01

Stes, A., Gijbels, D., \& Van Petegem, P. (2008). Student-Focused Approaches to Teaching in Relation to Context and Teacher Characteristics. Higher Education, 55, 255-267. https://doi.org/10.1007/s10734-007-9053-9

Sun, J., Liu, J., Wu, Y., \& Li, S. (2014). The Effects of the Student-Centered Clinical Nursing Practice Mode Based on the Action Research for Clinical Practicum of Undergraduate Students in Beijing, China. Procedia-Social and Behavioral Sciences, 14, 839-845. https://doi.org/10.1016/j.sbspro.2014.05.146

Trigwell, K., \& Prosser, M. (1996). Changing Approaches to Teaching: A Relational Perspective. Studies in Higher Education, 21, 275-284.

https://doi.org/10.1080/03075079612331381211

UFAM (2015). Relatório CPA da Autoavaliação 2015. http://www.cpa.ufam.edu.br/attachments/article/20/RelatorioAutoavaliacao2015Versa oFinalINEP.pdf

UFRJ (2016). Relatório de Autoavaliação Institucional 2016-Ano base 2015-Parcial I. http://pi.pr1.ufrj.br/images/UFRJ-CPA-2016.pdf

UnB (2012). Relatório de Avaliação Institucional 2012. http://www.dpo.unb.br/index.php?option=com_phocadownload\&view=category\&dow $\underline{\text { nload=382:relatorio-autoavaliacao-2012\&id=91:autoavaliacao-institucional } \& \text { Itemid }=68}$ $\underline{6}$ 
UnB (2013). Relatório de Avaliação Institucional 2013.

http://www.dpo.unb.br/index.php?option=com_phocadownload\&view=category\&dow $\underline{\text { nload=383:relatorio-autoavaliacao-2013\&id=91:autoavaliacao-institucional\&Itemid }=68}$ $\underline{6}$

UnB (2014). Relatório de Avaliação Institucional 2014. http://www.dpo.unb.br/index.php?option=com_phocadownload\&view=category\&dow nload=384:relatorio-autoavaliacao-2014\&id=91:autoavaliacao-institucional\&Itemid $=68$ 6

UnB (2015). Relatório de Avaliação Institucional 2015. http://www.dpo.unb.br/index.php?option=com_phocadownload\&view=category\&dow nload=379:relatorio-autoavaliao-2015\&id=91:autoavaliacao-institucional\&Itemid=686

UnB (2016). Relatório de Avaliação Institucional 2016.

http://www.dpo.unb.br/index.php?option=com_phocadownload\&view=category\&dow nload=559:relatorio-de-autoavaliacao-institucional-2016\&id=91:autoavaliacao-instituci onal\&Itemid $=686$

UTFPR (2015). Relatório de Autoavaliação Institucional da UTFPR-2015.

http://www.utfpr.edu.br/estrutura-universitaria/diretorias-de-gestao/diretoria-de-gesta o-da-avaliacao-institucional/cpa-comissao-propria-de-avaliacao/2015_relatorio-de-aut oavaliacao/view 


\section{Appendix}

Table A1. Categories of students' experiences in student-centred course.

\begin{tabular}{|c|c|c|}
\hline Theme & Examples of original quotes extracts ${ }^{1}$ & $\begin{array}{l}\text { Amount of } \\
\text { students }\end{array}$ \\
\hline $\begin{array}{l}\text { Increased will to } \\
\text { become a teacher }\end{array}$ & $\begin{array}{l}\text { "Courses like this increase my will to become a teacher, } \\
\text { [they are] a great encouragement" } \\
\text { "I was not much interested on it [becoming a teacher], } \\
\text { after the course I'm thinking about the possibility of } \\
\text { teaching at youth and adult education" }\end{array}$ & 4 \\
\hline $\begin{array}{l}\text { Growth on } \\
\text { dedication and } \\
\text { effort }\end{array}$ & $\begin{array}{l}\text { "I've become a better student as the classes went by" } \\
\text { "At this course I put a lot of effort to be a good student" } \\
\text { "[I am] More aware of my difficulties and studying } \\
\text { better" }\end{array}$ & 16 \\
\hline Significant learning & $\begin{array}{l}\text { "[the course was] very useful to reflect about mine and } \\
\text { my teachers pedagogical practices and to try to find } \\
\text { ways to be a better teacher" } \\
\text { "Although I am enrolled at this course for the third time, } \\
\text { this time I've learned the subject better" }\end{array}$ & 16 \\
\hline $\begin{array}{l}\text { Good and } \\
\text { motivational } \\
\text { classes }\end{array}$ & $\begin{array}{l}\text { "Classes were super interesting, did not make me feel } \\
\text { sleepy (very important!)" } \\
\text { "Classes were fun and challenging" } \\
\text { "It was essential to explore different possibilities of } \\
\text { teaching, because, otherwise, classes are like lectures that } \\
\text { for students (especially the younger ones) are a torture" }\end{array}$ & 21 \\
\hline $\begin{array}{l}\text { Surprised with the } \\
\text { course }\end{array}$ & $\begin{array}{c}\text { "It was surprising, because I expected it [the course] } \\
\text { to be boring" } \\
\text { "I was surprised about how much I got involved } \\
\text { with the classes" } \\
\text { "I do not like to study Psychology, did not have any } \\
\text { good expectation for this course, so I was surprised it } \\
\text { was good." }\end{array}$ & 15 \\
\hline
\end{tabular}

${ }^{1}$ Translated from portuguese. 